\title{
CHEMICAL AND BIOLOGICAL CHARACTERISTICS OF DIFFERENT HYDRATED MONOCALCIUM PHOSPHATES FOR BROILER CHICKENS*
}

\author{
Dorota Jamroz ${ }^{1}$, Agnieszka Gajda-Janiak ${ }^{1}$, Zbigniew Wzorek ${ }^{2}$, \\ Zygmunt Kowalski ${ }^{2}$, Janusz Kubizna ${ }^{1}$
}

\author{
${ }^{1}$ Department of Animal Nutrition and Feed Quality, Wrocław University of Environmental and Life \\ Sciences, ul. Chełmońskiego 38C, 51-630 Wrocław, Poland \\ ${ }^{2}$ Institute of Chemistry and Inorganic Technology, Cracow University of Technology, Warszawska 24, \\ 31-015 Kraków, Poland \\ Corresponding author: dorota.jamroz@up.wroc.pl
}

\begin{abstract}
Three hydrated monocalcium phosphates differing in purity (with or without monetite, or monetite and calcite) and in crystalline structure were used in broiler chickens diets. The performance indices, concentration of $\mathrm{Ca}, \mathrm{P}$ and $\mathrm{Mg}$ and activity of alkaline phosphatase in blood plasma, the content of these mineral elements in bones, and physico-mechanical parameters of femur and tibia bones were recorded. Body weight on 35th day of life, feed intake and mechanical parameters of bone quality were slightly affected by the type of phosphates used. Higher $\mathrm{Ca}$ and $\mathrm{P}$ concentration in blood was stated in chickens fed diets with greater purity of phosphates, but activity of alkaline phosphatase has increased with the admixture of monetite or calcite used in phosphates. The best parameters of bone quality were found in the treatment in which hydrated monocalcium phosphate (MCP) with admixture of monetite and calcite was applied. Higher concentration of both Ca and $\mathrm{Mg}$ in bone was determined in chickens fed diets with pure phosphates.
\end{abstract}

Key words: phosphates, solubility, structure, bones

Phosphorus is an integral ingredient of active organic compounds in live organisms - phosphoproteins, enzymes and bone components. It is utilized at the cell level as adenosine triphosphate (ATP) to generate energy, and it participates in phosphorylation, in metabolism and absorption processes. About $80-95 \%$ of the total pool of $\mathrm{P}$ in organism is incorporated in bones. The native sources of phosphorus for poultry are phytates found in great amounts in grain. However, these mineral compounds are

*Work supported by Ministry of Scientific Research and Information Technology, Poland, project no. 1199/T09/2004/27. 
less or even totally unavailable to poultry. This makes it necessary to enrich the feed mixtures with phosphates (and/or apply the additional microbial enzyme phytase) (Orban et al., 1999; Rama Rao and Ramasubba Reddy, 2003). Depending on the type of chemical bonds, the phosphorus from phosphates is characterized by different degrees of bioavailability (Barauch et al., 1958; Coffey et al., 1994; De Groote and Huyghebaert, 1997; Fernandes et al., 1999; Nelson et al., 1990; Bleux et al., 2002). The biological value of different feed phosphates available on the commercial feed market directly depends on technology of production, chemical composition and purity, content of calcium, particle size and on many other factors (Gillis et al., 1954; Gajda-Janiak et al., 2005; Ravindran, 1995; Wzorek and Kowalski, 1995). The great variation in phosphate quality resulted in a large body of studies of chemical composition and crystallographic and physical characteristics of 341 different mono-, di-, tri-, Mg- and Na- phosphates available on the Polish feed market (Jamroz et al., 2010). The purpose of this study was to determine the quality of different phosphates in diets for chickens in terms of potential availability of phosphorus from these chemical compounds. In the first trial three monocalcium phosphates characterized by different physicochemical properties were selected for evaluation based on the performance, $\mathrm{Ca}, \mathrm{P}$ and $\mathrm{Mg}$ contents in blood as well as chemical composition and mechanical properties of bones of broiler chickens.

\section{Material and methods}

\section{Animals and feed mixtures}

Three hundred one-day-old Hubbard Flex male chicks with an average body weight of $45.5 \pm 1.6 \mathrm{~g}$ were randomly divided into three dietary treatments, each comprised of ten replications (cages) with 10 birds/cage. The chickens were reared in battery cages. The ambient temperature was gradually reduced from 32 to $21^{\circ} \mathrm{C}$, the lighting programme was 24 hours light per day in the first week, after which the lights were turned off for 6 hours daily. Birds had free access to drinking water and to the feeders with feed mixtures given in mash form ad libitum (days 1-10 prestarter, days 11-21 starter, and days 22-35 grower diet). Three analogue mixtures were used. The birds of all treatments were fed isoprotein and isoenergetic diets based on wheat, maize and soybean meal (Table 1), but in experimental groups different MCP were introduced to the diets.

The phosphates differed in physicochemical characteristics (Table 2; Figs. 1-3). The roentgenographic and thermogravimetric characteristics made it possible to identify the crystalline phases of phosphates on the basis of melting temperature of crystal diffraction and interference of wave on the crystal walls. These data are important information for the technologists. In mixtures given in treatment I pure MCP was applied, in treatment II MCP with monetite, and in treatment III MCP with monetite and calcite were used. The examined phosphates were characterized by different solubility in water (Table 2), but the use of citric acid, $\mathrm{HCl}$ and ammonium citrate as solvents made this parameter similar for all the phosphates used (Table 2). 
Table 1. Composition of experimental diets $(\mathrm{g} / \mathrm{kg})$

\begin{tabular}{|c|c|c|c|c|c|c|c|c|c|}
\hline \multirow{3}{*}{ Item } & \multicolumn{9}{|c|}{ Diets } \\
\hline & \multicolumn{3}{|c|}{ Prestarter } & \multicolumn{3}{|c|}{ Starter } & \multicolumn{3}{|c|}{ Grower } \\
\hline & I & II & III & I & II & III & I & II & III \\
\hline Wheat & 221.0 & & & 222.5 & & & 247.0 & & \\
\hline Maize & 353.0 & & & 353.0 & & & 353.0 & & \\
\hline Soybean meal & 339.2 & & & 331.5 & & & 297.1 & & \\
\hline Soya oil & 33.4 & & & 41.6 & & & 54.7 & & \\
\hline Premix $1 \% *$ & 10.0 & & & 10.0 & & & 10.0 & & \\
\hline DL Methionine $98 \%$ & 3.1 & & & 2.9 & & & 2.8 & & \\
\hline L Lysine 98\% & 0.9 & & & 0.5 & & & 1.0 & & \\
\hline $\mathrm{NaCl}$ & 2.8 & & & 2.8 & & & 2.9 & & \\
\hline $\mathrm{MCP} * *$ & 16.0 & & & 13.9 & & & 12.0 & & \\
\hline Limestone & 20.9 & 20.4 & 19.8 & 21.8 & 21.4 & 20.8 & 19.1 & 19.6 & 19.1 \\
\hline $\mathrm{ME}(\mathrm{MJ} / \mathrm{kg})$ & 12.2 & & & 12.4 & & & 12.9 & & \\
\hline \multicolumn{10}{|c|}{ Determined analytically } \\
\hline Crude protein & 225.1 & & & 221.5 & & & 207.5 & & \\
\hline Crude fat & 63.1 & & & 71.0 & & & 83.6 & & \\
\hline Crude fibre & 33.6 & & & 33.4 & & & 32.8 & & \\
\hline Met + Cys & 9.3 & & & 9.1 & & & 7.5 & & \\
\hline Lysine & 12.5 & & & 12.0 & & & 8.9 & & \\
\hline $\mathrm{Ca}$ & 10.5 & & & 10.5 & & & 9.5 & & \\
\hline P total & 7.8 & & & 7.3 & & & 6.7 & & \\
\hline $\mathrm{P}$ available $* * *$ & 5.0 & & & 4.5 & & & 4.0 & & \\
\hline $\mathrm{Mg}$ & 1.8 & & & 1.7 & & & 1.7 & & \\
\hline
\end{tabular}

*Provided per $\mathrm{kg}$ of prestarter/starter: vit. A - 12000 I.U., vit. $\mathrm{D}_{3}-3000$ I.U., vit. E - $35 \mathrm{mg}$, vit. $\mathrm{K}_{3}-$ $2.5 \mathrm{mg}$, vit. $\mathrm{B}_{1}-3 \mathrm{mg}$, vit. $\mathrm{B}_{2}-7 \mathrm{mg}$, vit. $\mathrm{B}_{6}-5 \mathrm{mg}$, vit. $\mathrm{B}_{12}-0.02 \mathrm{mg}$, biotin $-0.15 \mathrm{mg}$, nicotinic acid (PP) $40 \mathrm{mg}$, calcium pantothenate $-14 \mathrm{mg}$, folic acid $-1.5 \mathrm{mg}$, choline $-600 \mathrm{mg}, \mathrm{Mn}-70 \mathrm{mg}, \mathrm{Fe}-70 \mathrm{mg}, \mathrm{Cu}-$ $15 \mathrm{mg}, \mathrm{Zn}-60 \mathrm{mg}$, Se $-0.2 \mathrm{mg}$, Co $-0.3 \mathrm{mg}, \mathrm{I}-1 \mathrm{mg}$, coccidiostat Salinomycin $-60 \mathrm{mg}$;

Provided per kg of grower: vit. A - 10000 I.U., vit. $\mathrm{D}_{3}-2000$ I.U., vit. E - $30 \mathrm{mg}$, vit. $\mathrm{K}_{3}-1.5 \mathrm{mg}$, vit. $\mathrm{B}_{1}-2 \mathrm{mg}$, vit. $\mathrm{B}_{2}-5 \mathrm{mg}$, vit. $\mathrm{B}_{6}-3 \mathrm{mg}$, vit. $\mathrm{B}_{12}-0.015 \mathrm{mg}$, biotin $-0.15 \mathrm{mg}$, nicotinic acid (PP) $-25 \mathrm{mg}$, calcium pantothenate $-10 \mathrm{mg}$, folic acid $-0.8 \mathrm{mg}$, choline $-500 \mathrm{mg}, \mathrm{Mn}-60 \mathrm{mg}, \mathrm{Fe}-50 \mathrm{mg}, \mathrm{Cu}-15 \mathrm{mg}$, $\mathrm{Zn}-50 \mathrm{mg}$, Se $-0.2 \mathrm{mg}, \mathrm{Co}-0.2 \mathrm{mg}, \mathrm{I}-0.7 \mathrm{mg}$.

**Monocalcium phosphates presented in Figs. 1, 2 and 3 and in Table 2.

***Calculated according to the available phosphorus content in dietary compound according to Smulikowska and Rutkowski (2005).

Mineral-vitamin premixes used in the mixtures were free of feed antibiotic or alternative substances and contained the coccidiostat. The crude protein content was about $220 \mathrm{~g} / \mathrm{kg}$ in prestarter and starter diets and $207 \mathrm{~g} / \mathrm{kg}$ in grower diet. The nutrients as well as amino acids were chemically determined in the separate components and then controlled analytically again in complete feed mixtures, and the averages for each diet differing in type of phosphate were presented in Table 1. 


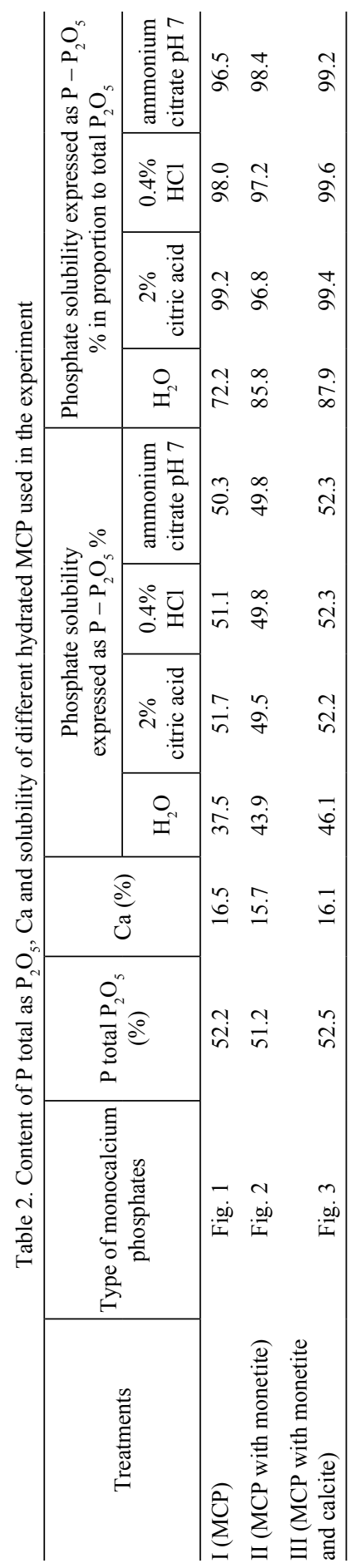


The energy value of diets was calculated to be $12.2 / 12.9 \mathrm{MJ} / \mathrm{kg}$, respectively on the basis of determined nutrients and according to the formula published in the European Tables of Energy Values of Feeds for Poultry (WPSA, 1989).

All procedures that were carried out with animals have been approved by the Local Ethics Commission for experiments with animals.

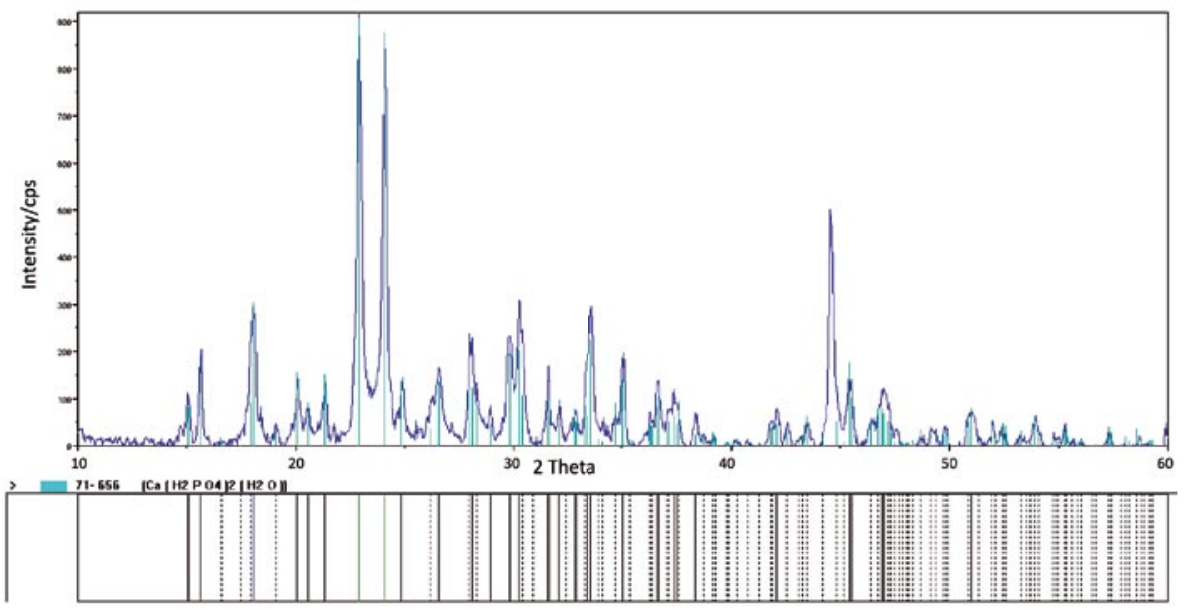

Sample: 103 fost-1-Ca Size: $21.6360 \mathrm{mg}$

TGA-DTA

File: C.ITAIDatal SDTPWr.107 Operator: ZW Run Date: 20-Apr-05 14:55

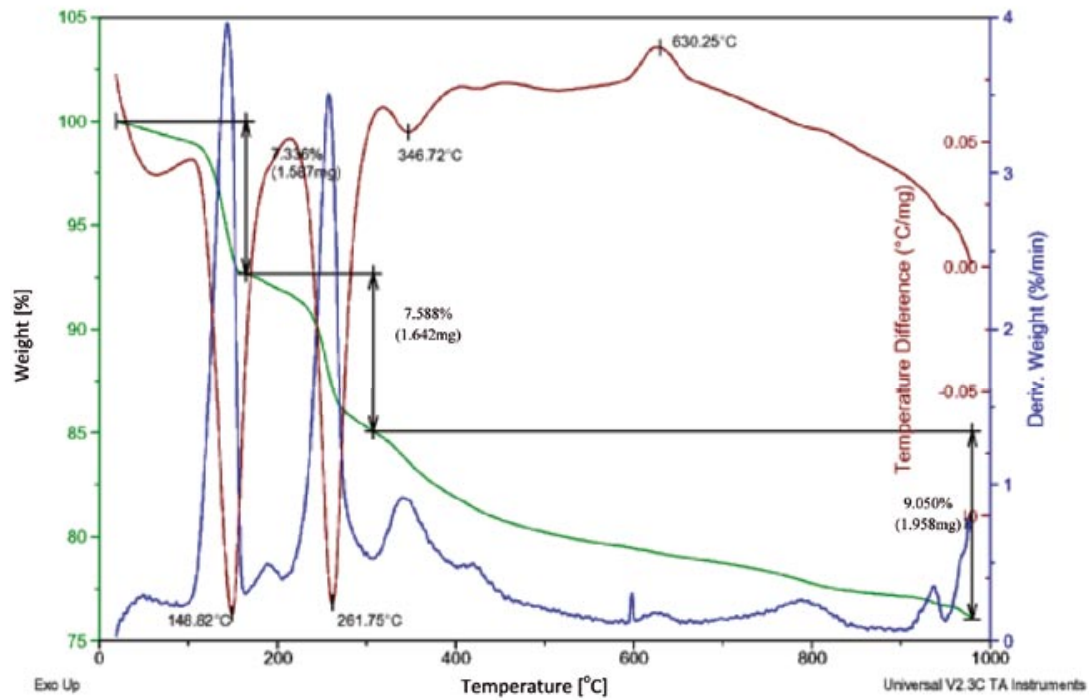

Fig. 1. Roentgenogram and thermogravimetric analysis of pure hydrated monocalcium phosphate used in treatment I (with about $96 \% \mathrm{MCP}$ ) 

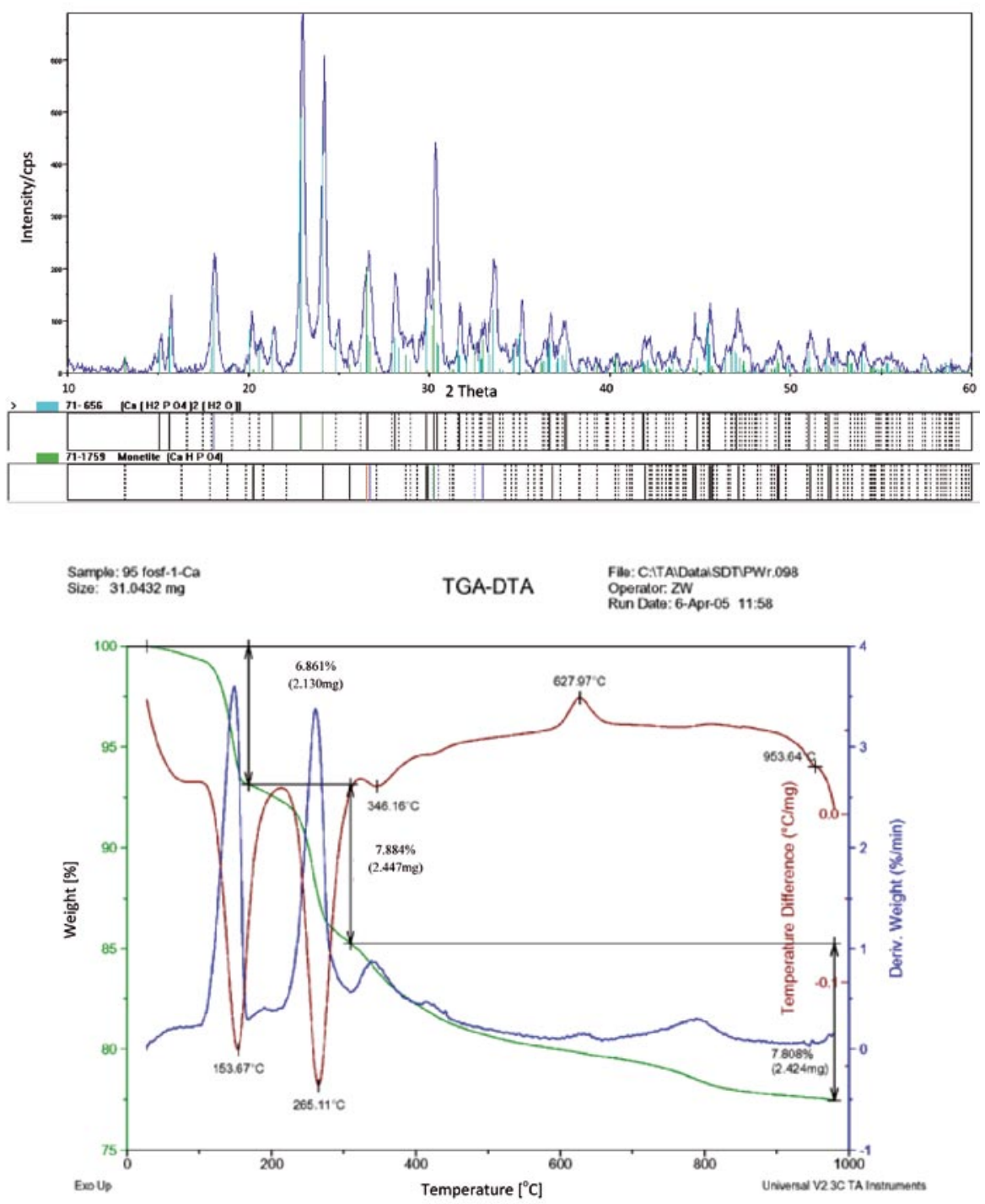

Fig. 2. Roentgenogram and thermogravimetric analysis of hydrated monocalcium phosphate (MCP) and monetite used in treatment II (with about 93\% MCP) 

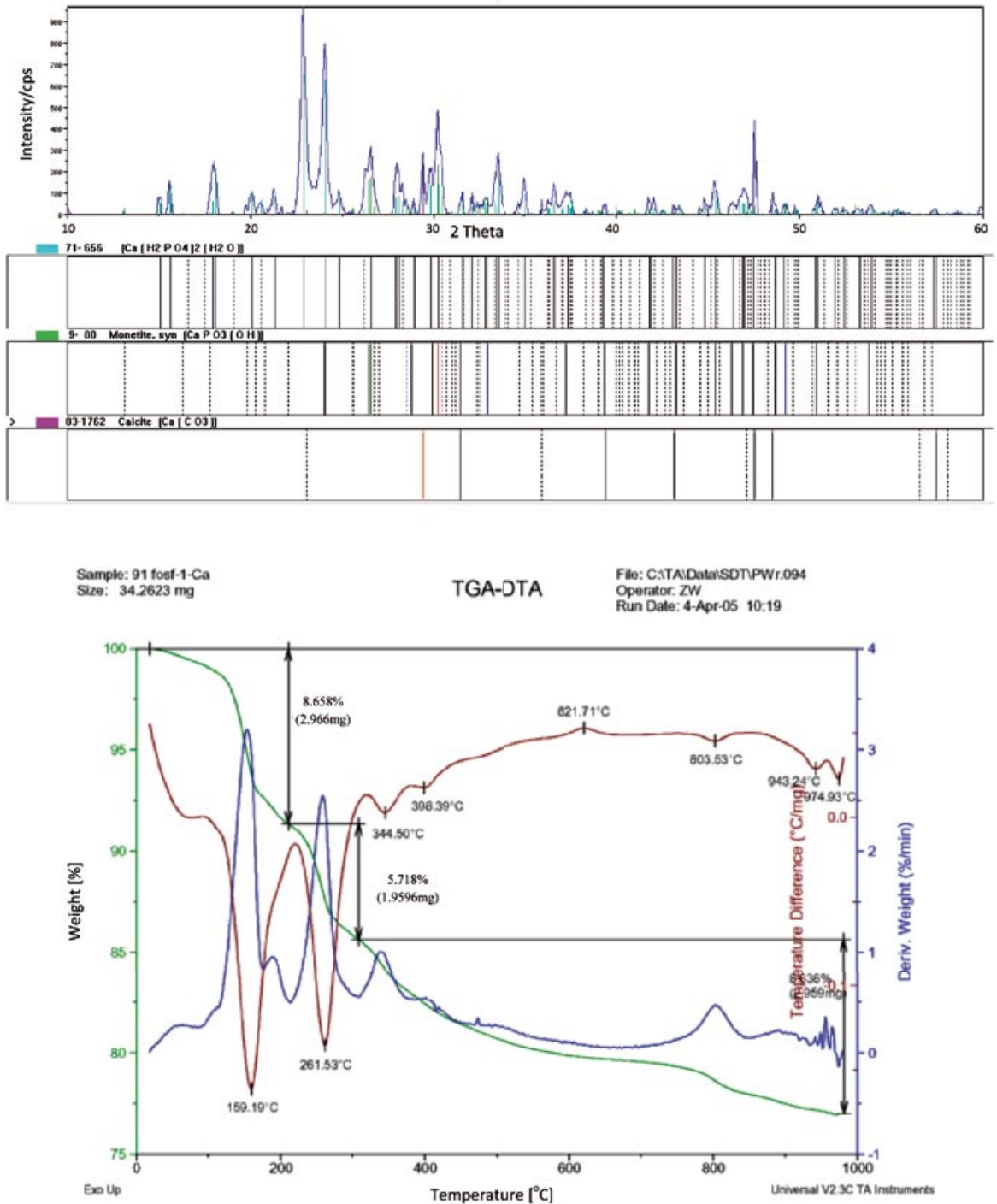

Fig. 3. Roentgenogram and thermogravimetric analysis of hydrated monocalcium phosphate (MCP) and monetite and calcite used in treatments III (with about 92\% MCP) 


\section{Experimental data}

The body weight of birds of each replicate-cage was determined on days 1, 21 and 35. Moreover, feed intake was recorded for the period of 1-21 and 22-35 days of age as well as for the whole experimental period. The feed mixtures were given twice a day in amounts that could be eaten completely in a short time. Mortality was recorded daily and reasons for mortality were analysed.

On day 35 post-hatch all chickens were individually weighed, after which 16 birds from each treatment ( 1 or 2 birds per replication) were randomly selected (in \pm average weight within replication). Birds were killed by cervical dislocation and both legs were cut off. The muscles were removed, and the femur and tibia bones were cleaned and stored for estimation of quality parameters (32 bones per treatment). For mechanical measurements, 16 femurs and 16 tibias were used. The same number of bones was sampled for chemical analysis using procedures described by Kim et al. (2004) and Jamroz et al. (2004, 2007). Mechanical parameters such as breaking strength (maximal force causing break of bone) and deflection were determined in fresh bones using the Instron 5544 (USA) apparatus. The bone deflection was measured by a standard method, in which the force (F) was applied to the shaft of bone supported on both epiphyses, at $\mathrm{L}=13 \mathrm{~mm}$ distance for estimations. The advance value of head during breaking force estimation on Instron apparatus was $0.8 \mathrm{~mm} / \mathrm{min}$ for bones of 35-day-old birds. Force (F) was increased up to the bone breaking moment. The elasticity coefficient $\mathrm{F} / \mathrm{h}$ was calculated. On the basis of mechanical measurements, the maximal loading force Fn (force at break point), maximal bone deflection hn (deflection at break point), maximum bone deflection $\mathrm{Un}=\mathrm{hn} / \mathrm{L}$ and breaking work (work needed to break the bone) were calculated. The detailed technique of measurements was presented by Jamroz et al. (2004).

Bones were defatted in ether extract for 24 hours according to the Soxhlet method and dried at $45^{\circ} \mathrm{C}$, and crude ash and the $\mathrm{Ca}, \mathrm{P}$ and $\mathrm{Mg}$ content were determined.

\section{Chemical analytical methods}

Analyses of the diets were carried out according to the standard AOAC (2005) methods: the nitrogen content by Kjeldahl method using a Kjeltec 2300 apparatus (Foss Tecator, Höganäs, Sweden); crude protein by multiplying the N-content by 6.25; crude fat by ether extraction; crude fibre by the Henneberg-Stohmann method using a Fibertec Tecator apparatus (Sweden); phosphorus in phosphates, experimental diets and bones was analysed after previous mineralization with nitric acid $\left(\mathrm{HNO}_{3}\right)$ and perchloric acid $\left(\mathrm{HClO}_{4}\right)$ by the ammonium vanadomolybdate method using a Specol 11 (Carl Zeiss Jena) spectrophotometer at a wavelength of $470 \mathrm{~nm}$; calcium and magnesium in diets and bones were determined by atomic absorption spectrophotometry using AA 240 FS type apparatus (Candela).

The amino acids in dietary components and diets were determined analytically. The results of these analyses were applied in simplex optimization of amino acids content in feed mixtures and then determined in complete mixtures again.

The chemical composition of feed phosphates was assayed on the basis of the method described by the European Chemical Industry Council (Cefic) Brussels, Inorganic Feed Phosphates Quality. Total phosphorus content, expressed in oxide 
form as $\mathrm{P}_{2} \mathrm{O}_{5}$ (Regulation 2003/2003/EC, method 3.2) was determined by gravimetric method using quinoline phosphomolybdate (dissolving samples in mixture (1:3 v:v) of hydrochloric acid $\left(\mathrm{HCl} ; 1.19 \mathrm{Mol} / \mathrm{dcm}^{3}\right)$ and nitric acid $\left(\mathrm{HNO}_{3} ; 1.4 \mathrm{Mol} /\right.$ $\mathrm{dcm}^{3}$ ) in boiling temperature). Calcium in phosphates was determined after dissolving in nitric acid complexometric with disodium versenate $\left(2.02 \mathrm{Mol} / \mathrm{dcm}^{3}\right)$ by indicator fluorexone with thymolphthalein. The solubility of phosphorus from inorganic phosphates was tested according to the methods recommended by the European Chemical Industry Council (Environmental Protection Agency, 2003). The following characteristics were examined: solubility in water; solubility in $2 \%$ citric acid (Regulation 2003/2003/EC, method 3.1.3; temp. $20^{\circ} \mathrm{C}$, 35-40 min., P-content determined with gravimetric method using quinoline phosphomolybdate); solubility in $0.4 \% \mathrm{HCl}$; solubility in ammonium citrate $\mathrm{pH} 7$ (Regulation 2003/2003/EC, method 3.1.5; temp. $65^{\circ} \mathrm{C}$, alkaline citrate from bi-ammonium citrate, $\mathrm{pH} 9.4-9.7 ; 30 \mathrm{~min}$. $+60 \mathrm{~min}$. by gravimetric method using quinoline phosphomolybdate).

\section{Statistical analysis}

Data were evaluated statistically by one-factorial ANOVA using StatSoft Statistica ${ }^{\circledR}$ computer software (2005). The differences for all parameters were tested according to the following statistical model:

$$
Y_{i j}=\mu+a_{i}+e_{i j}
$$

where $Y_{i j}$ means the variance associated with parameter a, $\mu$ is the overall mean, $a_{i}$ is the treatment effect (type of phosphate), $e_{i j}$ is the error. The cage-replication measurements or individual data for blood and bone parameters were treated as the experimental units and differences between treatment means were analysed for significance $(\mathrm{P}<0.01$ or 0.05$)$ using Tukey's test. The data are presented as means and are accompanied by SEM.

\section{Results}

The average body weight of chickens on days 21 and 35 post-hatch was similar in all treatments except treatment III (MCP with monetite and calcite) on day 21 $(\mathrm{P}<0.05)$ as compared to other treatments. The average daily feed intake calculated for the period of 1-35 days was $70 \mathrm{~g}$. This value was slightly lower in treatment III $(\mathrm{P}>0.05)$ (Table 3$)$. Similar mortality of birds was observed in all treatments.

Table 3. Performance of chickens for the period of 1-35 days of life

\begin{tabular}{|c|c|c|c|c|}
\hline \multirow{2}{*}{ Item } & \multicolumn{3}{|c|}{ Treatments } & \multirow{2}{*}{$\begin{array}{c}\text { Pooled } \\
\text { SEM }\end{array}$} \\
\hline & I & II & III & \\
\hline \multicolumn{5}{|l|}{ Body weight (g) } \\
\hline on 21 st day of life & $717 \mathrm{ab}$ & $732 \mathrm{a}$ & $704 \mathrm{~b}$ & 5.951 \\
\hline on 35 th day of life & 1857 & 1866 & 1829 & 12.380 \\
\hline Average feed intake during $1-35$ days of life (g/day/head) & 70.4 & 70.5 & 67.6 & 0.910 \\
\hline Mortality $(\%)$ & 2.0 & 2.0 & 1.0 & \\
\hline
\end{tabular}

Differences between groups marked with a, b were significant at $\mathrm{P}<0.05$. 
Table 4. Content of $\mathrm{Ca}, \mathrm{P}$ and $\mathrm{Mg}$ and alkaline phosphatase activity in blood serum in 35-day-old chickens

\begin{tabular}{l|c|c|c|c}
\hline \multirow{2}{*}{\multicolumn{1}{c|}{ Item }} & \multicolumn{3}{c|}{ Treatments } & \multirow{2}{*}{ Pooled SEM } \\
\cline { 2 - 5 } & $\mathrm{I}$ & $\mathrm{II}$ & III & \\
\hline $\mathrm{Ca}(\mathrm{mmol} / \mathrm{l})$ & $2.92 \mathrm{a}$ & $3.18 \mathrm{~b}$ & $2.70 \mathrm{a}$ & 0.100 \\
$\mathrm{P}(\mathrm{mmol} / \mathrm{l})$ & $2.91 \mathrm{a}$ & $3.07 \mathrm{~b}$ & $2.91 \mathrm{a}$ & 0.001 \\
$\mathrm{Mg}(\mathrm{mmol} / \mathrm{l})$ & 1.19 & 1.15 & 1.14 & 0.001 \\
Alkaline phosphatase activity (U/l) & $1822 \mathrm{a}$ & $2202 \mathrm{~b}$ & $2183 \mathrm{~b}$ & 76.35 \\
\hline
\end{tabular}

Differences between groups marked with $\mathrm{a}, \mathrm{b}$ were significant at $\mathrm{P}<0.05$.

Table 5. Physical and strength parameters of femur and tibia bones in 35-day-old chickens

\begin{tabular}{|c|c|c|c|c|}
\hline \multirow{2}{*}{ Item } & \multicolumn{3}{|c|}{ Treatments } & \multirow{2}{*}{ Pooled SEM } \\
\hline & I & II & III & \\
\hline \multicolumn{5}{|c|}{ Femur bone } \\
\hline Maximum breaking force $(\mathrm{N})$ & 194.9 & 204.7 & 215.1 & 1.402 \\
\hline Elasticity (N/m) & $1.21 \times 10^{5}$ & $1.17 \times 10^{5}$ & $1.28 \times 10^{5}$ & $0.92 \times 10^{3}$ \\
\hline $\begin{array}{l}\text { Surface of cross-section at breaking } \\
\text { point }\left(\mathrm{mm}^{2}\right)\end{array}$ & 44.4 & 45.1 & 46.7 & 0.265 \\
\hline Young's module $\left(\mathrm{N} / \mathrm{m}^{2}\right)$ & $4.63 \times 10^{9}$ & $4.25 \times 10^{9}$ & $4.65 \times 10^{9}$ & $0.72 \times 10^{8}$ \\
\hline & \multicolumn{4}{|c|}{ Tibia bone } \\
\hline Maximum breaking force $(\mathrm{N})$ & 349.7 & 354.3 & 382.0 & 3.587 \\
\hline Elasticity (N/m) & $2.39 \times 10^{5} \mathrm{a}$ & $2.54 \times 10^{5} \mathrm{a}$ & $2.93 \times 10^{5} \mathrm{~b}$ & $0.30 \times 10^{4}$ \\
\hline $\begin{array}{l}\text { Surface of cross-section at breaking } \\
\text { point }\left(\mathrm{mm}^{2}\right)\end{array}$ & 44.9 & 48.8 & 45.4 & 0.332 \\
\hline Young's module (N/m²) & $9.91 \times 10^{9}$ & $9.60 \times 10^{9}$ & $1.25 \times 10^{10}$ & $0.19 \times 10^{9}$ \\
\hline
\end{tabular}

Differences between groups marked with $\mathrm{a}$, $\mathrm{b}$ were significant at $\mathrm{P}<0.05$.

The blood serum parameters showed variability caused by the feed phosphates used. The significantly highest $\mathrm{Ca}$ concentration in blood serum was found in chickens from treatment II (MCP with monetite) $(\mathrm{P}<0.05)$. The phosphorus level in serum also was significantly higher in the same treatment $(\mathrm{P}<0.05)$ and that of $\mathrm{Mg}$ in treatment I (pure MCP) $(\mathrm{P}>0.05)$ (Table 4). The type of dietary phosphate caused differences in activity of alkaline phosphatase (E.C. 3.1.3.1.), which was significantly higher in blood from chickens of treatment II and III $(\mathrm{P}<0.05)$. The mechanical parameters of femur and tibia were similar (Table 5). The best parameters of bone quality, although not significantly different (except elasticity in treatment III) were noted in treatment III, in which phosphates with other Ca compounds were applied in the diets. The chemical composition of bones can provide real information on the utilization of mineral substances in animal organism, but the results obtained did not confirm such expectation (Table 6). The type of phosphate used had a significant effect on crude ash content in femur bones. The highest amount of ash was determined 
in bones of chickens of treatment I $(\mathrm{P}<0.05)$; similarly, the concentration of $\mathrm{Ca}$ and $\mathrm{Mg}$ in crude ash was the highest in treatment I. The differences in phosphorus concentration among treatments were found to be insignificant. In tibia ash content no differences as a result of phosphates used can be seen, but the incorporation of $\mathrm{Ca}$, $\mathrm{P}$ and $\mathrm{Mg}$ into bones was significantly different in particular treatments, and the $\mathrm{Ca}$ and $\mathrm{Mg}$ content in tibia was greater in treatment $\mathrm{I}(\mathrm{P}<0.01 ; 0.05$, respectively). Similarly to the femur bone, higher Ca content was determined in bones of chickens from treatments I and II and Mg in treatment I than in treatment III. Unclear convergence was observed between physical parameters and chemical composition of bones.

Table 6. Content of crude ash, $\mathrm{Ca}, \mathrm{P}, \mathrm{Mg}$ in femur and tibia bone in 35-day-old chickens

\begin{tabular}{|c|c|c|c|c|}
\hline \multirow{2}{*}{ Item } & \multicolumn{3}{|c|}{ Treatments } & \multirow{2}{*}{ Pooled SEM } \\
\hline & $\mathrm{I}$ & II & III & \\
\hline & \multicolumn{4}{|c|}{ Femur bone } \\
\hline Crude ash (\%) & $41.5 \mathrm{a}$ & $39.9 \mathrm{~b}$ & $39.9 \mathrm{~b}$ & 0.300 \\
\hline \multicolumn{5}{|c|}{ Contents in ash $(\mathrm{g} / \mathrm{kg})$} \\
\hline $\mathrm{Ca}$ & $206.9 \mathrm{a}$ & $201.2 \mathrm{a}$ & $192.5 \mathrm{~b}$ & 1.442 \\
\hline $\mathrm{P}$ & 171.3 & 173.0 & 171.0 & 0.700 \\
\hline \multirow[t]{2}{*}{$\mathrm{Mg}$} & $7.3 \mathrm{a}$ & $6.6 \mathrm{~b}$ & $6.7 \mathrm{~b}$ & 0.102 \\
\hline & \multicolumn{4}{|c|}{ Tibia bone } \\
\hline Crude ash (\%) & 40.2 & 39.3 & 39.6 & 0.007 \\
\hline \multicolumn{5}{|c|}{ Contents in ash $(\mathrm{g} / \mathrm{kg})$} \\
\hline $\mathrm{Ca}$ & $202.6 \mathrm{a}$ & $200.5 \mathrm{a}$ & $193.9 \mathrm{~b}$ & 1.095 \\
\hline $\mathrm{P}$ & $169.5 \mathrm{a}$ & $168.7 \mathrm{a}$ & $171.5 \mathrm{~b}$ & 0.600 \\
\hline $\mathrm{Mg}$ & $7.1 \mathrm{~A}$ & $6.2 \mathrm{~B}$ & $6.3 \mathrm{C}$ & 0.101 \\
\hline
\end{tabular}
$\mathrm{P}<0.01$.

Differences between groups marked with $\mathrm{a}, \mathrm{b}$ were significant at $\mathrm{P}<0.05$; with $\mathrm{A}, \mathrm{B}, \mathrm{C}$ significant at

\section{Discussion}

The investigations concerning evaluation of phosphorus sources and determination of chemical and biological value of feed phosphates were already conducted for many years (Baruah et al., 1958), but still are carried out today (Rodehutscord, 2009). Our own extensive study was focused not only on the physicochemical properties of feed phosphates, including the solubility in different solvents, but also on the parameters that rarely are taken into consideration in biological investigations. The crystalline phases of phosphates were evaluated using X-ray irradiation and the percentage of hydrated and dehydrated phases was assayed thermally. In our own investigations over 340 production batches of feed phosphates were analysed (Jamroz et al., 2010). These studies have shown that the mono- and dicalcium phosphates dif- 
fer in the solubility parameters to a small degree only. However, greater differences were found in purity and crystalline phase. The biological implications of recognized crystalline structure of different feed phosphates are unknown. Such questions were the basis of the current study in which different types of phosphates were introduced into diets for young chickens. Three typical types of phosphates: pure MCP (I) or MCP with monetite (II) or MCP with monetite and calcite (III) were chosen for biological assays. In the present study a significant decrease in body weight was stated only in 21-day-old chickens from the treatment in which MCP with three other components was applied in mixture. In both feed intake and conversion indices, only small differences among treatments were stated. In the current study the concentrations of $\mathrm{Ca}$ and $\mathrm{P}$ in blood serum were highest in chickens of treatment II (MCP with monetite), but these significant differences among treatments do not clearly reflect the real value of analysed phosphates. Other authors reported that the substantial differences in opinions and interpretation of P-availability depended on its source (Gillis et al., 1954; Baruah et al., 1958; Sullivan et al., 1992; Coffey et al., 1994; Ravindran et al., 1995; De Groote and Huyghebaert, 1997; Lima et al., 1999; Bleux et al., 2002; Rodehutscord and Dieckman, 2005). Different methods used in estimation of P-availability cause that direct comparison of our own results with data presented by other authors is almost impossible. The development and chemical composition of bones remains in close relationship to the type of phosphorus source and its level in the diets (Orban et al., 1999; Rath et al., 2000; Jamroz et al., 2001, 2004, 2007; Hemme et al., 2004; Almeida et al., 2005; Tatara et al., 2006; Krawczyk et al., 2007; Onyango and Adeola, 2009). In the present study the different composition and purity of MCP was associated with some changes in bone breaking force, which was lower in chickens from treatment I (pure MCP) as in other treatments (MCP with monetite or with monetite and calcite). The type of phosphorus source had no clear effect on other characteristics of bones related to their quality and chemical composition.

In conclusion, the body weight on 35 th day of life, feed intake and also mechanical parameters of bone quality were slightly affected by the type of hydrated monocalcium phosphates used. Higher $\mathrm{Ca}$ and $\mathrm{P}$ concentration in blood was stated in chickens fed diets with greater purity of phosphates, but the activity of alkaline phosphatase in blood increased in chickens fed diets with phosphates and Ca compounds. The best parameters of bone quality were found in treatments in which MCP with $\mathrm{Ca}$ compounds were used. Higher concentration of both $\mathrm{Ca}$ and $\mathrm{Mg}$ in bone was determined in chickens fed diets with pure phosphates.

\section{References}

A $1 \mathrm{~m}$ e i d a Paz I.C.L., Mendes A.A., Takita T.S., Vulc ano L.C., Guerra P.C., We chs ler F.S., Garcia R.G., T a kahashi S.E., More ir a J., P elíc i a K., Ko mi y a ma C.M., Quinte iro R.R. (2005). Comparison of techniques for tibial dyschondroplasia assessment in broiler chickens. Braz. J. Poultry Sci., 7, 1: 27-31.

AOAC (2005) Official Methods of Analysis of Association of Official Analytical Chemists; AOAC International. Ed.: Cunniff. P. 17th Edition AOAC International: Arlington. VA. 
B a r u a h J.N., R e i d B.L., C o u c h J.R. (1958). A comparison of methods for estimating phosphorus availability. Poultry Sci., Abstr., 37: 1183.

Bleux W., Engellandt T., Zwart J. (2002). The phosphorus digestibility of 3 feed phosphates for broilers. Proc. 7th Tagung Schweine - u. Geflügelernährung, Halle-Lutherstadt, pp. 207-209.

C offey R.D., M o o n e y K.W., C ro mw e 11 G.L., A a r o n D.K. (1994). Biological availability of phosphorus in defluorinated phosphates with different phosphorus solubilities in neutral ammonium citrate for chicks and pigs. J. Anim. Sci., 72, 10: 2653-2660.

De Groote G., Huyghebaert G. (1997). The bio-availability of phosphorus from feed phosphates for broilers as influenced by bio-assay method, dietary Ca-level and feed form. Anim. Feed Sci. Techn., 69: 329-340.

EPA (2003). National pollutant discharge elimination system permit regulation and effluent limitation guidelines and standards for concentrated animal feeding operations: Final rule. Federal Register, February 12, 68: 7175-7274.

European Tables of Energy Values for Poultry Feedstuffs (1989). WPSA, Wageningen, The Netherlands, 3rd ed., pp. 11-28.

Fernandes J.I.M., Lima F.R., Mendonca Jr C.X., Mabe I., Albuquerque R., L e a 1 P.M. (1999). Relative bioavailability of phosphorus in feed and agricultural phosphates for poultry. Poultry Sci., 78: 1729-1736.

Gajd a - J a n i a k A., J a m roz D., W z orek Z. (2005). Physico-chemical properties of phosphates applied in animal feeding. Pol. J. Chem. Tech., 7: 20-23.

Gi 11 i s M.B., N or r i s L.C., H e u s e r G.F. (1954). Studies on the biological value of inorganic phosphates. J. Nutr., 52: 115-125.

He m me A., S park M., W olf P., Pas chertz H., Kamphues J. (2004). Effects of different phosphorus sources in the diet on bone composition and stability (breaking strength) in broilers. J. Anim. Physiol. Anim. Nutr., 89: 129-133.

Jamroz D., Gajd a - Jan i a k A., W z orek Z., Kow a ls ki Z. (2010). Physico-chemical evaluation of feed phosphates as a criterion of their classification. Krmiva, 52, 6: 299-315.

Jamroz D., Wertelecki T., Żyłka R., Schleicher A. (2001). Retention of calcium and phosphorus from different phosphates and their influence on bone mineralization in chickens. Chem. Agricult. Czech Republ., 2: 365-371.

Jamroz D., Wertelecki T., Żyłka R., Bodarski R., Gajda-Janiak A. (2004). Mechanical, chemical and spectroscopic analysis of mineralisation rate as methods of bones quality determination in broiler chickens. Electr. J. Polish Agricult. Univ., Series Animal Husbandry, http://www.ejpau.media.pl/volume7/issue2/animal/art-04.html

J a m roz D., Werte le c ki T., Ży łk a R. (2007). The retention of mineral substances quality and chemical composition of bones in chickens fed diets containing different calcium and phosphorus level. Electr. J. Polish Agricult. Univ., Series Animal Husbandry, www.ejpau.media.pl/articles/ volume10/issue 3/art-04.html

K i m W.K., D on ald s on L.M., Herrera P., W o o d w ard C.L., K u be n a L.F., N is b e t D.J., R i c ke S.C. (2004). Research note: Effects of different bone preparation methods (fresh, dry, and fat-free dry) on bone parameters and correlation between bone breaking strength and the bone parameters. Poultry Sci., 83: 1663-1666.

Krawczyk A., Kuropka P., Kuryszko J., Wall A., Dragan S., Kulej M. (2007). Experimental studies on the effect of osteotomy technique on the bone regeneration in distraction osteogenesis. Bone, 40, 3: 781-791.

L i m a F.R., F ernandes J.I.M., O live ir a E., Fronzagli a G.C., K a h n H. (1999). Laboratory evaluations of feed-grade and agricultural-grade phosphates. Poultry Sci., 78: 1717-1728.

N e l s o n T.S., K i r b y L.K., J o h n s o n Z.B. (1990). The relative biological value of feed phosphates for chicks. Poultry Sci., 69: 113-118.

On y a n g o E.M., A d e o l a O. (2009). Dietary phytate (inositol hexaphosphate) regulates the activity of intestinal mucosa phytase. J. Anim. Physiol. Anim. Nutrit., 93: 639-646.

Orban J.I., A d e ol a O., S tros hine R. (1999). Microbial phytase in finisher diets of White Pekin ducks: effect on growth performance, plasma phosphorus concentration, and leg bone characteristics. Poultry Sci., 78: 366-377. 
R a m a R a o S.V, R a m a s u b b a R e d d y V. (2003). Relative bio-availability and utilisation of phosphatic fertilisers as sources of phosphorus in broilers and layers. Brit. Poultry Sci., 44, 1: 96-103.

Rath N.C., Huff G.R., Huff W.E., B a log J.M. (2000). Factors regulating bone maturity and strength in poultry. Poultry Sci., 79: 1024-1032.

R avindran V., K o r n e g a y E.T., P o t t e r L.M., O g u n ab a m e r u B.O., W e 1 t e n M.K., W i 1 s o n J.H., P otchan a k or n M. (1995). An evaluation of various response criteria in assessing biological availability of phosphorus for broilers. Poultry Sci., 74: 1820-1830.

R o d e h u t s c ord M. (2009). Approaches and challenges for evaluating phosphorus sources for poultry. Proc. 17th Europ. Symp. Poultry Nutrit., Edinburgh, pp. 2-6.

R o d e hut s c ord M., D i e k man n A. (2005). Comparative studies with three-week-old chickens, turkeys, ducks and quails on the response in phosphorus utilization to a supplementation of monobasic calcium phosphate. Poultry Sci., 84: 1252-1260.

S mulikowska S., Rutkowski A. (2005). (Editors). Recommended allowances and nutritive value of feedstuffs. Poultry feeding standards (in Polish). 4th Edition. The Kielanowski Institute of Animal Physiology and Nutrition, PAS, Jabłonna, Polish Branch of WPSA, pp. 110-113.

S u 11 i va n T.W., D o u g l a s J.H., G on z a l e z N.J., B on d Jr. P.L. (1992). Correlation of biological value of feed phosphates with their solubility in water, dilute hydrogen chloride, dilute citric acid, and ammonium citrate. Poultry Sci., 71: 2065-2074.

T a t ara M.R., Tyges en M.P., S aw a - Woj tanow ic z B., Harris on A.P. (2006). The impact of bone development on final carcass weight. Arch. Tierzucht, Special Issue, 49: 132-136.

W z o r e k Z., K o w a l s k i Z. (1995). Thermal method of feed phosphate production using phosphorus salts (in Polish). Przem. Chem., 74, 12: 463-466.

Accepted for printing 2 I 2012

\section{DOROTA JAMROZ, AGNIESZKA GAJDA-JANIAK, ZBIGNIEW WZOREK, ZYGMUNT KOWALSKI, JANUSZ KUBIZNA}

\section{Chemiczna i biologiczna charakterystyka uwodnionych fosforanów jednowapniowych w dietach dla kurcząt rzeźnych}

\section{STRESZCZENIE}

Trzy rodzaje uwodnionych fosforanów jednowapniowych różniących się czystością (zawierających monetyt lub monetyt i kalcyt) i strukturą krystaliczną wprowadzono do diet kurcząt brojlerów. Rejestrowano wskaźniki produkcyjne, koncentrację $\mathrm{Ca}, \mathrm{P}$ i $\mathrm{Mg}$ i aktywność fosfatazy alkalicznej w osoczu krwi, koncentrację tych składników w kościach oraz parametry fizyko-mechaniczne kości udowej i piszczelowej. Masa ciała w 35. dniu życia, średnie pobranie paszy, a także mechaniczne wskaźniki jakości kości podlegały małej zmienności w zależności od rodzaju zastosowanych fosforanów. Wyższą koncentrację Ca i P w surowicy oznaczono u kurcząt żywionych mieszanką zawierającą fosforany o większej czystości, natomiast aktywność fosfatazy alkalicznej była najwyższa przy zastosowaniu fosforanu z domieszką $\mathrm{CaHPO}_{4}$ (monetyt) oraz $\mathrm{CaCO}_{3}$ (kalcyt). Najkorzystniejsze parametry jakości kości wystąpiły u kurcząt z grupy, w której zastosowano fosforany z największą ilością domieszek. Wyższą ilość Ca i Mg oznaczono w kościach kurcząt żywionych mieszanką zawierającą czysty fosforan jednowapniowy. 